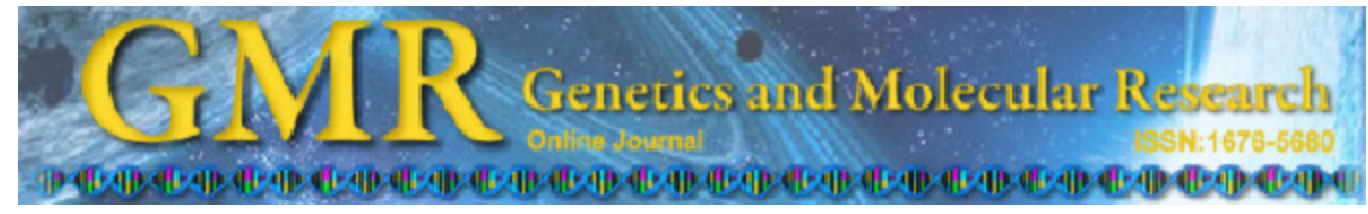

\title{
Microsatellite isolation and characterization for Colletotrichum spp, causal agent of anthracnose in Andean blackberry
}

\author{
M.L. Marulanda, A.M. López, L. Isaza and P. López \\ Facultad de Ciencias Ambientales, Universidad Tecnológica de Pereira, \\ Pereira, Colombia \\ Corresponding author: M.L. Marulanda \\ E-mail: ubioteve@utp.edu.co \\ Genet. Mol. Res. 13 (3): 7673-7685 (2014) \\ Received June 27, 2013 \\ Accepted January 27, 2014 \\ Published September 26, 2014 \\ DOI http://dx.doi.org/10.4238/2014.September.26.5
}

\begin{abstract}
The genus Colletotrichum, comprised of pathogenic fungi that affect plants grown worldwide, causes the disease known as anthracnose in several fruit and vegetable species. Several studies conducted on plants have shown that the disease is characterized by the presence of one or several species of the fungus attacking the fruit or other organs of the same host. To develop and implement effective control strategies, it is vital to understand the genetic structure of the fungus in agricultural systems, identify associated Colletotrichum species, and define the subpopulations responsible for the disease. Molecular tools were accordingly developed to characterize genotypic populations of Colletotrichum spp, causal agent of anthracnose in commercial crops of Andean blackberry (Rubus glaucus Benth.). A microsatellite-enriched library for Colletotrichum gloeosporioides was developed to identify and characterize microsatellite loci among isolates collected in $R$. glaucus plantations. Thirty microsatellites were developed and tested in 36 isolates gathered from eight different blackberry-production areas of Colombia. Ten pairs of microsatellites were polymorphic.
\end{abstract}

Key words: Simple sequence repeats; Colletotrichum acutatum; Anthracnose; Colletotrichum gloeosporioides; Rubus glaucus; Colombia 


\section{INTRODUCTION}

The genus Colletotrichum contains some of the world's most economically important phytopathogenic fungi, which together with the teleomorph Glomerella cingulata, are among the pathogens most studied by scientists, because each year they are responsible for significant production losses in many tropical, subtropical, and temperate crops worldwide, particularly cereal, vegetable, and fruit crops, as well as ornamental species (Freeman, 2000). Because of their high genetic plasticity and their dependency on environmental factors, these fungi constantly undergo physiological and morphological changes that affect their pathogenicity (Michereff, 2000). The fruit production of high-value crops in temperate markets, such as strawberry, mango, citrus, and avocado, as well as that of staple crops such as banana, is seriously affected. Colletotrichum species are responsible for causing a devastating disease that affects coffee berries in Africa, and also seriously affect maize, sugarcane, and sorghum. The genus was recently voted the eighth most important group of phytopathogenic fungi in the world, based on perceived scientific and economic importance (Dean et al., 2012).

Traditionally, Colletotrichum species have been identified and characterized on the basis of morphological characteristics, such as colony color and conidial size and shape (Gunnell and Gubler, 1992). However, these criteria are not sufficient to differentiate between Colletotrichum species because of the overlapping of morphological and phenotypic characters between species. The molecular techniques available nowadays offer more precise methods to conduct taxonomic studies, define species, study plant-pathogen relationships and, more recently, understand the structure of pathogen populations at an intraspecific level (MacLean et al., 1993).

Molecular techniques based on specific primers, such as the internal transcribed spacer (ITS), have become a very valuable tool for identifying Colletotrichum species (Brown et al., 1996). Disease control and management programs need to consider the molecular basis of the action of plant pathogens, including the structure and evolution of genes related to pathogenicity (Medeiros et al., 2010).

DNA techniques have become the most precise method to determine the genetic diversity and phylogeny of different fungal species (Bogale et al., 2009). Amplified fragment length polymorphism (AFLP) markers have been used in studies of fungal populations to distinguish species and phylogenetic groups. Microsatellites or simple sequence repeats (SSRs) have also been used to differentiate between fungal populations because of their high capacity to differentiate at the intraspecific level (Bogale et al., 2009).

Several studies have been conducted on microsatellite-enriched genomic libraries in phytopathogenic fungal species and their use in population analyses and genetic characterization, particularly in Colletotrichum species. One such study was that conducted by Ranathunge et al. (2009) to obtain SSRs of the causal agent of anthracnose in red pepper (Capsicum spp), using 27 microsatellites to characterize 52 isolates from different regions of India, Sri Lanka, and Thailand. Recently, microsatellite markers were also developed and applied to study isolates and populations of several phytopathogenic fungi, such as Rhizoctonia solani, Botrytis cinerea, Phytophthora infestans, Magnaporthe grisea, and Ascochyta rabiei (Ciampi et al., 2008; Ranathunge et al., 2009).

Anthracnose, a disease caused by the fungus Colletotrichum spp, mainly C. acutatum and C. gloeosporioides, occurs in all regions of Colombia where the Andean blackberry $(R u$ bus glaucus) is grown. Disease incidence ranges between 50 and $73 \%$, but can reach $100 \%$ in some cases (Tamayo, 2003). The incidence of C. gloeosporioides is higher in blackberry 
production areas in central-western Colombia. However, several Colletotrichum species that are morphologically indistinguishable are found to be related to a single host. Hence, the hostpathogen combination involved in the incidence of anthracnose is often insufficient to serve as a diagnostic indicator of disease etiology (Abang et al., 2003).

Studies carried out in strawberry indicate that anthracnose can be associated with more than one fungal species attacking the fruits or other organs of a single host plant (Freeman, 2000). In strawberry, anthracnose is caused by three different fungi: C. gloeosporioides, C. fragariae, and C. acutatum (Denoyes-Rothan et al., 2003; Mackenzie et al., 2006). Studies have also demonstrated that the fungal species $C$. fragariae and $C$. gloeosporioides are highly interrelated regarding morphological and pathological aspects. Both produce a reddish necrosis, which eventually causes plant death (Smith and Black, 1990).

The filamentous fungus $C$. gloeosporioides has been widely studied in several crops of temperate, tropical, and subtropical areas worldwide (Alahakoon et al., 1994). In Latin America, studies have been conducted on anthracnose caused by G. cingulata in R. glaucus in Venezuela (Cedeño and Palacios, 1992).

In Colombia, studies carried out by Afanador et al. (2006) and Marulanda et al. (2007) described Colletotrichum spp to be the causal agent of anthracnose, in particular C. gloeosporioides and C. acutatum and, in some cases, a combination of both fungi. In both studies, the isolates were submitted to molecular and morphological analyses using ITS. A preliminary conclusion of the research conducted by Afanador et al. (2006) was that the species C. acutatum was the causal agent of anthracnose in Andean blackberry; however, Marulanda et al. (2007) reported the presence of both $C$. gloeosporioides and C. acutatum associated with anthracnose in blackberry crops in Colombia's coffee-growing region, with C. gloeosporioides being the predominant species.

In the case of this group of cosmopolitan pathogens, information on populations may prove to be useful to help better understand the population structure of pathogens in crops, and it could explain the differences in pathogenicity between isolates of the same fungus (McDonald and Linde, 2002). Gene flow patterns can be identified by analyzing the distribution of genetic diversity within and between populations. A high degree of shared similarity or the detection of rare alleles present between geographically isolated populations is evidence of the gene flow between these populations, with possible consequences for the level of effectiveness of control strategies, in addition to demonstrating the existence of structured subpopulations (McDonald and Linde, 2002). Understanding the genetic structure of pathogen populations offers information about the pathogen's future evolutionary potential, which could prove to be useful not only in the search for resistance genes, but also in defining the appropriate use of fungicides in agriculture (McDonald and Linde, 2002; Ciampi et al., 2008). Temporal and spatial information on genetic diversity and population structure is highly important to understand evolutionary adaptability and the pathogen's potential to overcome the potential resistance of the host plant (Ciampi et al., 2008).

In this study, SSR molecular markers were developed to characterize genetic populations of Colletotrichum spp, the causal agent of anthracnose in commercial crops of Andean blackberry. This pioneer research on the population structure of $C$. gloeosporioides will also serve as a model to conduct research on C. gloeosporioides in other species. It is important to emphasize that $C$. gloeosporioides is a broad-range pathogen, also affecting soursop (Annona muricata), tree tomato (Cyphomandra betaceae), and mango (Mangifera indica), among other species (Cannon et al., 2012). 


\section{MATERIAL AND METHODS}

This study aimed to build a microsatellite-enriched genomic library and develop primers to characterize different populations of Colletotrichum spp, the causal agent of anthracnose in cultivars of $R$. glaucus.

\section{Developing microsatellite markers}

Microsatellite markers were developed at the Center for Molecular Biology and Genetic Engineering, Universidade Estadual de Campinas (UNICAMP) in Campinas, São Paulo, Brazil.

A microsatellite-enriched genomic library for C. gloeosporioides was constructed according to the methodology developed by Billotte et al. (1999) to identify and characterize microsatellite loci. Genomic DNA was extracted from single-spore mycelium of the fungus using the protocol of Lee and Taylor (1990) and $5 \mu \mathrm{g}$ DNA were digested with Afa 1 and ligated to the double-strand adaptors RSA21 (5'-CTCTTGCTTACGCGTGGACTA-3') and RSA25 (5'-TAGTCCACGCGTAAGCAAGAGCACA-3'). Enrichment was based on hybridization-based capture with $(\mathrm{GT})_{8}$ and $(\mathrm{CT})_{8}$ biotin-linked probes and streptavidin-coated magnetic beads (Streptavidin MagneSphere Paramagnetic Particles, Promega). Selected fragments were then cloned into pGEM-T Easy vectors (Promega) and inserted into the Escherichia coli DH5- $\alpha$ strain. Positive colonies were randomly selected by the blue/white screening protocol, and 72 clones were double sequenced on an ABI PRISM 377 automated sequencer (Applied Biosystems) using T7 and SP6 primers and the BigDye ${ }^{\circledR}$ Terminator v3.1 Cycle Sequencing kit (Applied Biosystems).

Raw sequences were identified using the SAT software (SSR Analysis Tool; Dereeper et al., 2007) and microsatellites showing di-, tri-, tetra-, penta-, or hexanucleotide motifs were edited, aligned, and, if redundant, eliminated using the SeqMan software (DNAStar). Primer pairs were designed with Gene Runner v3.05.

\section{Characterizing Colletotrichum populations}

\section{Collection of material}

Thirty-six isolates obtained from Andean blackberry crops located in eight blackberry-producing areas of the departments of Risaralda, Quindío, Caldas, Antioquia, Cundinamarca, Santander, Valle del Cauca, and Tolima, located in Colombia's Andean region, were selected for this study (Table 1). Samples were collected from leaves and branches exhibiting symptoms of anthracnose.

\section{Isolating the fungus}

Single-spore cultures isolated from samples collected in the field in the eight abovementioned departments of Colombia were placed in potato dextrose agar (PDA) culture medium, acidified with lactic acid. Spores were taken from pure isolates and placed in test tubes by depletion. 


\begin{tabular}{|c|c|c|c|}
\hline Sample & Species identified by specific primers & Collection site & Department \\
\hline 6 & C. gloeosporioides & $4^{\circ} 4^{\prime} 99.2^{\prime \prime} \mathrm{N} ; 75^{\circ} 41^{\prime} 86^{\prime \prime} \mathrm{W}$ & Risaralda \\
\hline SP & C. gloeosporioides & NA & Risaralda \\
\hline SCP & $\mathrm{NA}$ & NA & Risaralda \\
\hline SJM & C. gloeosporioides & NA & Risaralda \\
\hline SCJM & $\mathrm{NA}$ & NA & Risaralda \\
\hline 7D1 & C. gloeosporioides & $4^{\circ} 86^{\prime} 97.5^{\prime \prime} \mathrm{N} ; 5^{\circ} 66^{\prime} 50.5^{\prime \prime} \mathrm{W}$ & Risaralda \\
\hline 7D2 & C. gloeosporioides & $4^{\circ} 86^{\prime} 91.1^{\prime \prime} \mathrm{N} ; 75^{\circ} 66^{\prime} 52.7^{\prime \prime} \mathrm{W}$ & Risaralda \\
\hline 2B & C. gloeosporioides & $4^{\circ} 45^{\prime} 520^{\prime \prime} \mathrm{N} ; 75^{\circ} 38^{\prime} 16^{\prime \prime} \mathrm{W}$ & Risaralda \\
\hline $3 \mathrm{~S} 1$ & C. gloeosporioides & $5^{\circ} 12^{\prime} 55.1^{\prime \prime} \mathrm{N} ; 75^{\circ} 00^{\prime} 20.0^{\prime \prime} \mathrm{W}$ & Risaralda \\
\hline $3 \mathrm{~S} 2$ & C. gloeosporioides & $5^{\circ} 12^{\prime} 18.2^{\prime \prime} \mathrm{N} ; 75^{\circ} 00^{\prime} 28.2^{\prime \prime} \mathrm{W}$ & Risaralda \\
\hline $3 \mathrm{~S} 3$ & C. gloeosporioides & $5^{\circ} 12^{\prime} 29.5^{\prime \prime} \mathrm{N} ; 75^{\circ} 00^{\prime} 14.2^{\prime \prime} \mathrm{W}$ & Risaralda \\
\hline $4 \mathrm{~S} 1$ & C. gloeosporioides & $4^{\circ} 63^{\prime} 58.9^{\prime \prime} \mathrm{N} ; 75^{\circ} 56^{\prime} 94.2^{\prime \prime} \mathrm{W}$ & Quindío \\
\hline $4 \mathrm{~S} 2$ & C. gloeosporioides & $4^{\circ} 63^{\prime} 49.6^{\prime \prime} \mathrm{N} ; 75^{\circ} 56^{\prime} 98.3^{\prime \prime} \mathrm{W}$ & Quindío \\
\hline $4 \mathrm{~S} 3$ & C. acutatum & $4^{\circ} 59^{\prime} 97.1^{\prime \prime} \mathrm{N} ; 7^{\circ} 57^{\prime} 86.7^{\prime \prime} \mathrm{W}$ & Quindío \\
\hline $4 \mathrm{~S} 4$ & C. acutatum & NA & Quindío \\
\hline $1 \mathrm{M}$ & C. gloeosporioides & $5^{\circ} 22^{\prime} 9.7^{\prime \prime} \mathrm{N} ; 7^{\circ} 29^{\prime} 00.4^{\prime \prime} \mathrm{W}$ & Caldas \\
\hline $5 \mathrm{~V} 1$ & C. gloeosporioides & $4^{\circ} 57^{\prime} 49.9^{\prime \prime} \mathrm{N} ; 75^{\circ} 30^{\prime} 15.4^{\prime \prime} \mathrm{W}$ & Caldas \\
\hline $5 \mathrm{~V} 2$ & C. gloeosporioides & $4^{\circ} 57^{\prime} 48^{\prime \prime} \mathrm{N} ; 75^{\circ} 30^{\prime} 14.1^{\prime \prime} \mathrm{W}$ & Caldas \\
\hline $5 \mathrm{~V} 3$ & C. gloeosporioides & $4^{\circ} 57^{\prime} 46.7^{\prime \prime} \mathrm{N} ; 75^{\circ} 30^{\prime} 16.3^{\prime \prime} \mathrm{W}$ & Caldas \\
\hline $5 \mathrm{~V} 4$ & C. gloeosporioides & $4^{\circ} 57^{\prime} 44.7^{\prime \prime} \mathrm{N} ; 75^{\circ} 30^{\prime} 18.2^{\prime \prime} \mathrm{W}$ & Caldas \\
\hline A1 & C. acutatum & $6^{\circ} 16^{\prime} 38^{\prime \prime} \mathrm{N} ; 75^{\circ} 24^{\prime} 43^{\prime \prime} \mathrm{W}$ & Antioquia \\
\hline A3 & C. gloeosporioides & $6^{\circ} 16^{\prime} 49^{\prime \prime} \mathrm{N} ; 75^{\circ} 24^{\prime} 12^{\prime \prime} \mathrm{W}$ & Antioquia \\
\hline $\mathrm{C} 11$ & NA & $4^{\circ} 24^{\prime} 13^{\prime \prime} \mathrm{N} ; 74^{\circ} 19^{\prime} 24^{\prime \prime} \mathrm{W}$ & Cundinamarca \\
\hline C14 & NA & $4^{\circ} 24^{\prime} 28^{\prime \prime} \mathrm{N} ; 7^{\circ} 19^{\prime} 46^{\prime \prime} \mathrm{W}$ & Cundinamarca \\
\hline $\mathrm{C} 18$ & C. gloeosporioides & $4^{\circ} 24^{\prime} 55^{\prime \prime} \mathrm{N} ; 7^{\circ} 19^{\prime} 12^{\prime \prime} \mathrm{W}$ & Cundinamarca \\
\hline S24 & C. gloeosporioides & $6^{\circ} 59^{\prime} 39^{\prime \prime} \mathrm{N} ; 72^{\circ} 59^{\prime} 17^{\prime \prime} \mathrm{W}$ & Santander \\
\hline S31 & $\mathrm{NA}$ & $6^{\circ} 59^{\prime} 43^{\prime \prime} \mathrm{N} ; 72^{\circ} 59^{\prime} 28^{\prime \prime} \mathrm{W}$ & Santander \\
\hline S34 & NA & $6^{\circ} 59^{\prime} 56^{\prime \prime} \mathrm{N} ; 72^{\circ} 59^{\prime} 27^{\prime \prime} \mathrm{W}$ & Santander \\
\hline S36 & C. gloeosporioides & $6^{\circ} 59^{\prime} 58^{\prime \prime} \mathrm{N} ; 72^{\circ} 59^{\prime} 34^{\prime \prime} \mathrm{W}$ & Santander \\
\hline V38 & C. gloeosporioides & $3^{\circ} 466^{\prime} 50^{\prime \prime} \mathrm{N} ; 76^{\circ} 11^{\prime} 48^{\prime \prime} \mathrm{W}$ & Valle del Cauca \\
\hline V42 & C. gloeosporioides & $3^{\circ} 46^{\prime} 36^{\prime \prime N} ; 76^{\circ} 11^{\prime} 51^{\prime \prime} \mathrm{W}$ & Valle del Cauca \\
\hline V46 & $\mathrm{NA}$ & $3^{\circ} 46^{\prime} 31^{\prime \prime N} ; 76^{\circ} 11^{\prime} 47^{\prime \prime} \mathrm{W}$ & Valle del Cauca \\
\hline V54 & NA & $3^{\circ} 46^{\prime} 14^{\prime \prime} \mathrm{N} ; 76^{\circ} 11^{\prime} 25^{\prime \prime} \mathrm{W}$ & Valle del Cauca \\
\hline T59 & C. gloeosporioides & $4^{\circ} 17^{\prime} 77^{\prime \prime} \mathrm{N} ; 74^{\circ} 53^{\prime} 29^{\prime \prime} \mathrm{W}$ & Tolima \\
\hline $\mathrm{T} 63$ & C. gloeosporioides & $4^{\circ} 17^{\prime} 86^{\prime \prime N} ; 74^{\circ} 53^{\prime} 55^{\prime \prime} \mathrm{W}$ & Tolima \\
\hline $\mathrm{T} 82$ & C. gloeosporioides & $4^{\circ} 24^{\prime} 38^{\prime \prime N} ; 74^{\circ} 34^{\prime} 46^{\prime \prime} \mathrm{W}$ & Tolima \\
\hline
\end{tabular}

$\mathrm{NA}=$ data not available

\section{DNA extraction and species identification}

Mycelium had to be generated to be able to extract the DNA. Therefore, the 36 isolates were placed in liquid medium based on peptone, glucose, and yeast extract, subsequently filtered, cultured on PDA, and then left to develop at $35^{\circ} \mathrm{C}$ for three days. After incubation, the mycelium was collected and the DNA was extracted using the protocol described by Lee and Taylor (1990). To determine the species, DNA was amplified using universal primers from the rDNA conserved region as described by White et al. (1990) and the specific primers described by Brown et al. (1996): CgInt: 5'-GGCCTCCCGCCTCCGGGCGG-3' for C. gloeosporioides and CaInt2: 5'-GGCGCCGGCCCCGTCACGGGGG-3' for C. acutatum. Amplification reactions were performed in a final volume of $25 \mu \mathrm{L}$ with $0.01 \mathrm{mM}$ oligonucleotide CgInt, CaInt2 or ITS4, $250 \mathrm{mM}$ each dNTP, $1 \mathrm{X}$ reaction buffer, $1 \mathrm{U}$ Taq polymerase, $1.5 \mathrm{mM} \mathrm{MgCl}$ and 10 $\mathrm{ng} / \mu \mathrm{L}$ DNA. The amplification profile consisted of 40 cycles at $94^{\circ} \mathrm{C}$ for $30 \mathrm{~s}, 55^{\circ} \mathrm{C}$ for $30 \mathrm{~s}$, and $72^{\circ} \mathrm{C}$ for $2 \mathrm{~min}$. Fourteen isolates had been previously identified (Marulanda et al., 2007), 14 isolates were identified in this study, and eight isolates were not identified (Table 1). 


\section{Microsatellite characterization}

The microsatellite fragments were amplified by polymerase chain reaction (PCR) in $10-\mu \mathrm{L}$ reaction volumes, consisting of $10 \mathrm{ng}$ template DNA, $20 \mathrm{mM}$ Tris- $\mathrm{HCl}, 50 \mathrm{mM} \mathrm{KCl}, 2$ $\mathrm{mM} \mathrm{MgCl}, 0.2 \mathrm{mM}$ each dNTP, $0.3 \mu \mathrm{M}$ of each primer, and $0.5 \mathrm{U}$ Taq polymerase per reaction. PCR was performed according to the following parameters: $94^{\circ} \mathrm{C}$ for $4 \mathrm{~min}$; 10 cycles at $94^{\circ} \mathrm{C}$ for $30 \mathrm{~s}, 65^{\circ} \mathrm{C}\left(-1^{\circ} \mathrm{C} /\right.$ cycle $)$ for $30 \mathrm{~s}$, and $72^{\circ} \mathrm{C}$ for $1 \mathrm{~min} ; 35$ cycles at $94^{\circ} \mathrm{C}$ for $15 \mathrm{~s}$, annealing temperature $\left({ }^{\circ} \mathrm{C}\right.$ ) (Table 2) for $30 \mathrm{~s}$ and $72^{\circ} \mathrm{C}$ for $1 \mathrm{~min}$; and $72^{\circ} \mathrm{C}$ for $5 \mathrm{~min}$. Amplification products were visualized in polyacrylamide-bisacrylamide denaturing gels stained with silver nitrate (Benbouza et al., 2006).

\section{Statistical analysis}

Statistical analyses were carried out using the GenAlex v6.2 (Peakall and Smouse, 2006). Nei's genetic distance (1978) was calculated and a principal coordinates analysis performed. The polymorphism information content (PIC) was calculated for each SSR primer pair according to Cordeiro et al. (2003).

Using the same software, analysis of molecular variance (AMOVA) was used to determine the partitioning of genetic variation within and between groups by the SSR marker system.

\section{RESULTS AND DISCUSSION}

\section{Developing microsatellite markers}

The microsatellite-enriched library consisted of 96 clones, from which 53 (55.2\%) high-quality sequences were obtained. Of these 53 sequenced clones with microsatellite motifs, 30 primer pairs were complementary to sequences flanking the repeat motifs (Table 2). Of these 30 microsatellites, 10 showed polymorphisms in the populations analyzed, and 10 amplified samples of $C$. gloeosporioides and C. acutatum, demonstrating transferability of the microsatellite primers developed (Table 2).

Total PIC of the 10 microsatellite primer pairs showing polymorphism were quantified by amplifying Colletotrichum isolates (Table 2). Primers with the highest PIC values were CgE6-1 (0.7413), CgC12-1 (0.7066), and $\mathrm{CgG} 2$ (0.7003), and those showing the lowest PIC values were $\mathrm{CgF} 4(0.4553)$ and $\mathrm{CgD10}-3$ (0.4582), with the latter being referred to as less informative primers (Table 2). All markers displayed differences in terms of observed heterozygosity $\left(H_{\mathrm{O}}\right)$, with marker $\mathrm{CgC} 4-3$ showing the highest $H_{\mathrm{O}}$ at 0.958 and marker $\mathrm{CgF} 5-2$ the lowest value at 0.188 (Table 2).

The mean $H_{\mathrm{E}}$ value was 0.906 and the mean $H_{\mathrm{O}}$ value was 0.500 . According to Feres et al. (2009), the differences between $H_{\mathrm{E}}$ and $H_{\mathrm{O}}$ values can be attributed to the presence of null alleles, which mask heterozygous individuals as a single band. These results demonstrate that homozygosity was low. According to Montero et al. (1998), the genetic variability of $C$. gloeosporioides is high because this pathogen has a short life cycle and exhibits both sexual and asexual reproduction, with a resulting high rate of mutation and recombination by crossing. In summary, genetic diversity parameters serve to identify multiallelic markers and $H_{\mathrm{O}}$ values higher than $H_{\mathrm{E}}$ values. 
Microsatellite characterization for Colletotrichum spp

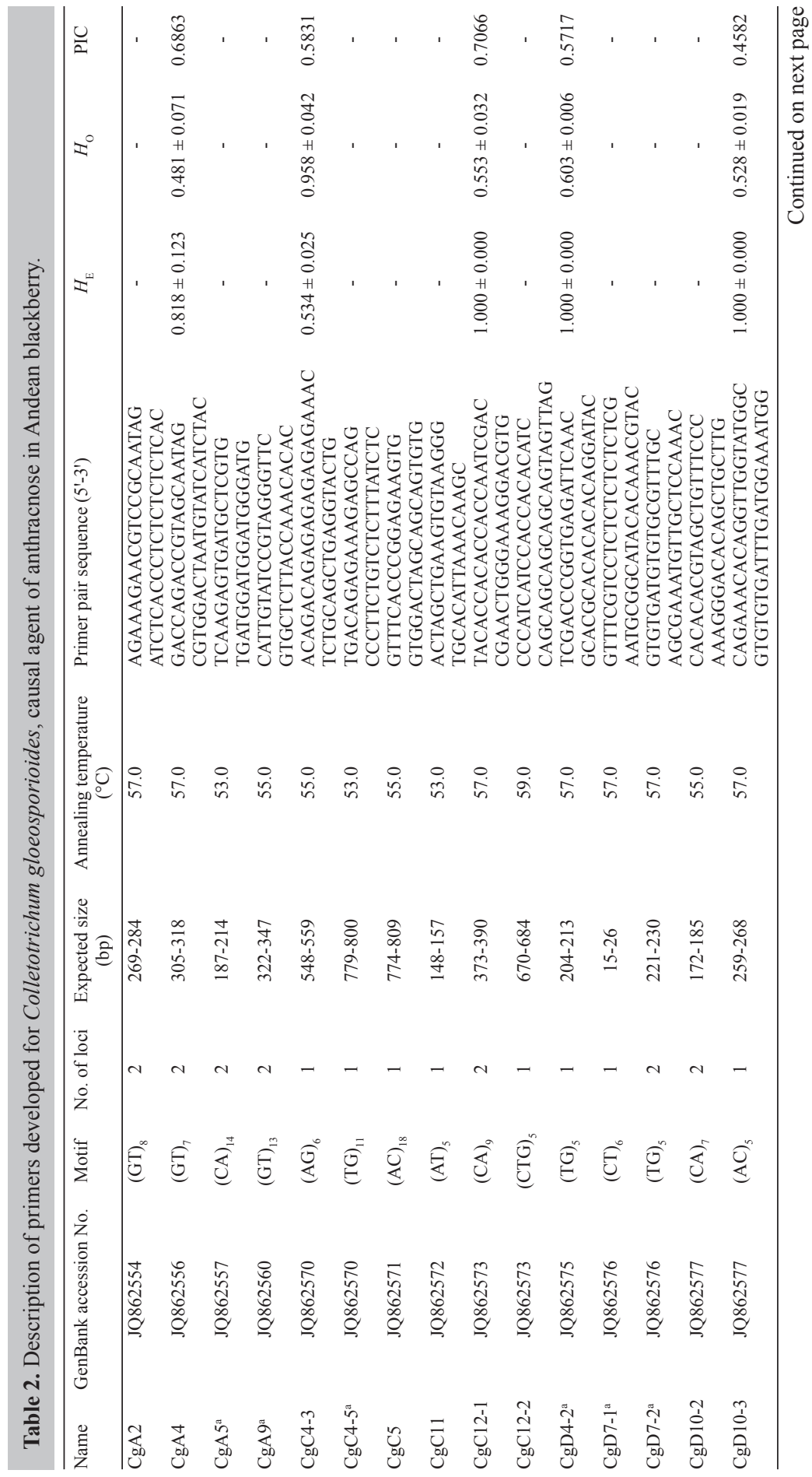




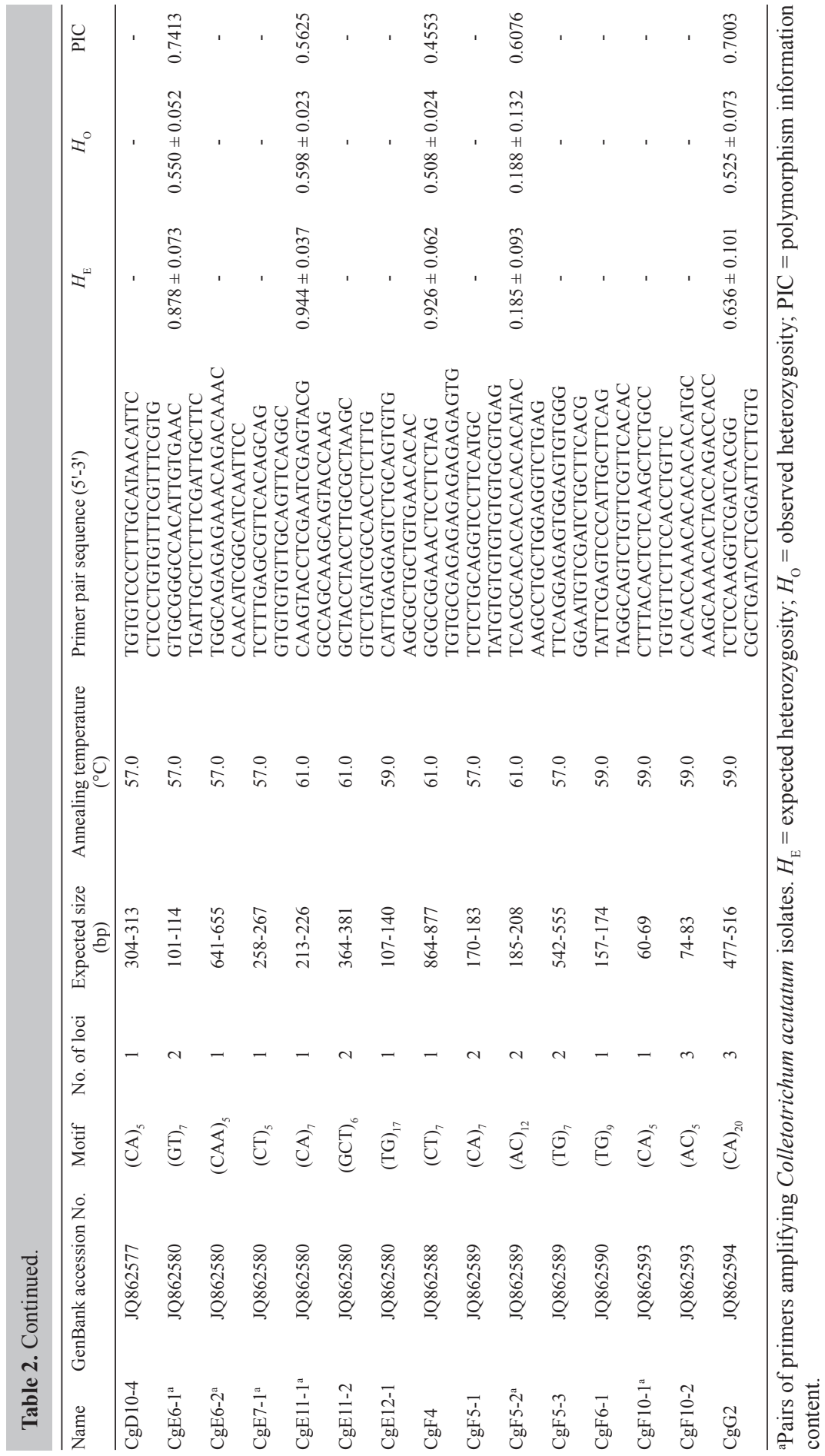




\section{Characterizing Colletotrichum populations}

Most primer pairs amplified one or two loci, with only primers $\mathrm{CgG} 2$ and $\mathrm{CgF} 10$ 2 amplifying three loci. $\mathrm{CgG} 2, \mathrm{CgC12}-1, \mathrm{CgE6}-1$, and $\mathrm{CgA} 9$ were multiallelic microsatellites. The locus CgA9 had the highest number of alleles (11 in total), followed by loci CgG2, CgG12-1, and CgE6-1 with 10 alleles each. Overall, 153 alleles were detected in the 46 loci, and the average of polymorphic loci was $95.11 \%$. Microsatellites CgD7-2, CgF5-2, CgC4-5, CgE6-1, $\mathrm{CgE} 12-1, \mathrm{CgC12}-1, \mathrm{CgA} 4, \mathrm{CgE} 11-1$, and $\mathrm{CgC} 12-1$ produced exclusive alleles that helped differentiate the isolates from different geographical regions such as Risaralda, Caldas, Cundinamarca, Santander, and Tolima.

In studies conducted by Ranathunge et al. (2009), the number of alleles was higher in 27 primer pairs developed and evaluated for another species of the same genus, C. capsici. Locus CCSSR1 showed 18 alleles detected across the 52 isolates and several common alleles within groups of isolates from India, Sri Lanka, and Thailand. Similarly, locus CCSSR53 revealed 11 different alleles and locus CCSSR59 nine alleles, with 141 alleles in 25 loci.

AMOVA results indicated that the highest percentage of variation $(80 \%)$ was within populations, followed by variation between populations (20\%) (Table 3). Masel et al. (1990) indicated that the genome of $C$. gloeosporioides populations is highly variable under field conditions, but the reason behind this polymorphism is unknown. Their results suggest, however, that chromosomal rearrangements can be considered a means to generate variability in this fungus.

Table 3. Data resulting from the analysis of molecular variance (AMOVA).
\begin{tabular}{lccc}
\hline Source & d.f. & Estimated variation & Variation (\%) \\
\hline Between populations & 7 & 4.880 & 20 \\
Within populations & 28 & 18.937 & 80 \\
Total & 35 & 23.817 & 100 \\
\hline
\end{tabular}

d.f. $=$ degrees of freedom.

McDonald and Linde (2002) also found that pathogens showing sexual reproduction or open growth pose a greater risk than when the reproductive pattern leads to inbreeding, because new genotypes emerge during the sexual cycle. Furthermore, the main mechanisms by which genetic diversity can be generated in populations of pathogenic microorganisms are mutation, population gene flow, and sexual and asexual recombination (Agrios, 1996).

Principal coordinate analysis was performed on the basis of the genetic distance between individuals (Figure 1). C. gloeosporioides isolates were observed to separate from $C$. acutatum isolates, which agrees with the results of Marulanda et al. (2007). In addition, genetic distance measurements showed some clustering of isolates regarding their geographical origin.

The clusters obtained in the genetic distance dendrogram (Figure 2) tended to form groups according to the place of origin of each isolate. Similar results have been reported in other host-pathogen interactions (González et al., 1998; Casarrubias-Carrillo et al., 2003). There was also a clear separation of samples corresponding to C. acutatum (4S3 and 4S4) from samples corresponding to C. gloeosporioides. 
M.L. Marulanda et al.

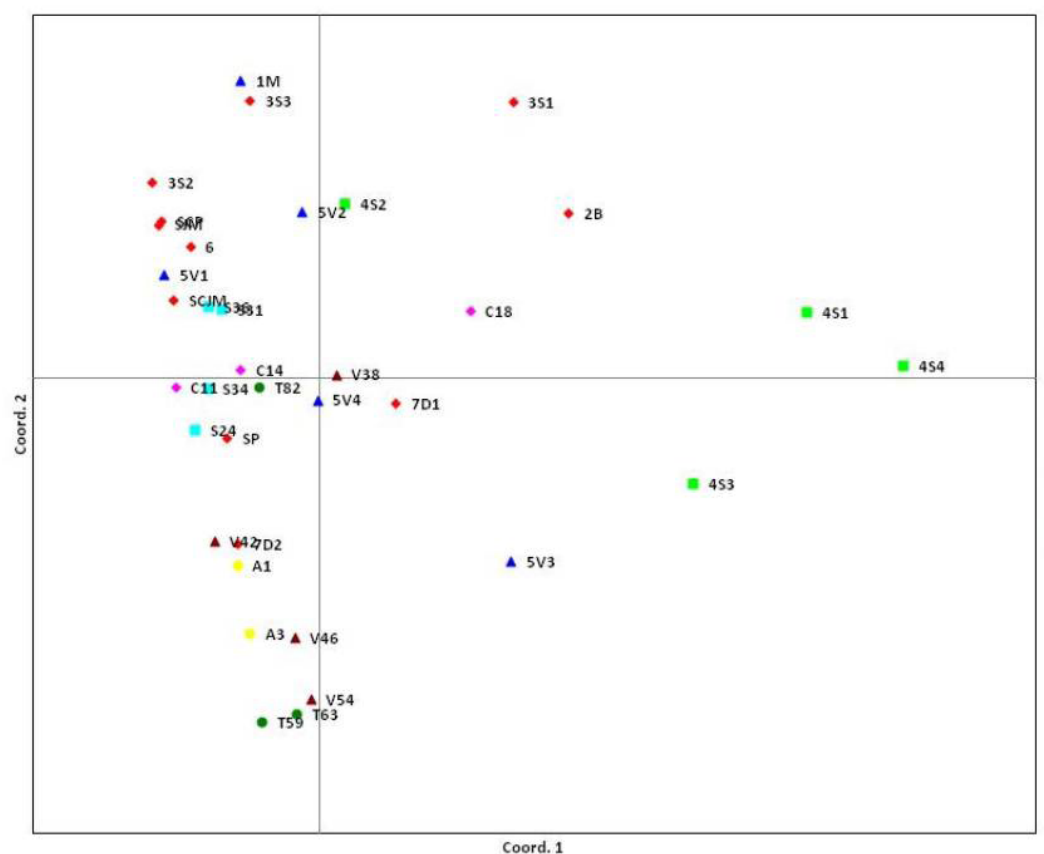

- Risaralda

= Quindio

$\triangle$ Caldas

Antioquia

- Cundinamarca

"Isantander

$\triangle$ valle

- Tolima

Figure 1. Principal coordinates analysis of Colletotrichum isolates.

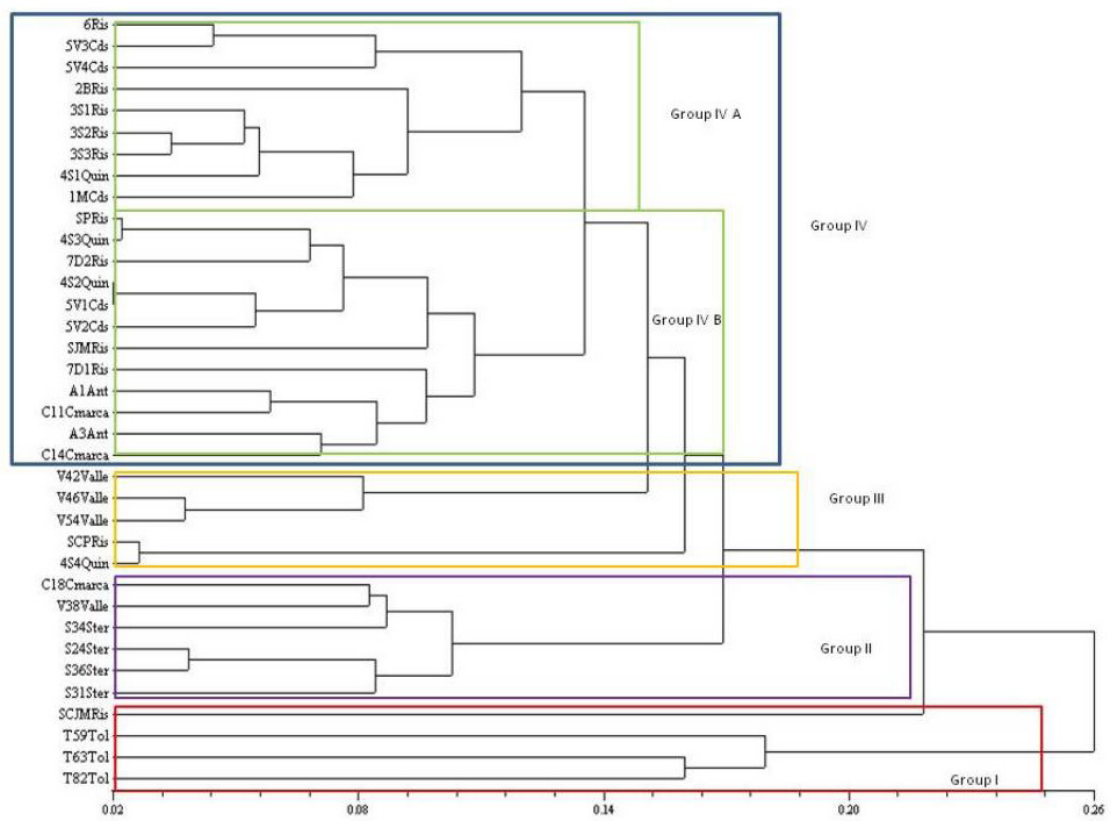

Figure 2. Dendrogram built based on Nei's distance coefficient (1978) and the UPGMA grouping method for SSR analysis of Colletotrichum isolates. 
In this study, four groups were formed (Figure 2). The first group consisted of $C$. gloeosporioides isolates T59, T63, and T68 from Tolima and exhibited the largest genetic distance regarding the other groups. The second group gathered isolates S34, S24, S36, and S31 from Santander and V38 from Valle del Cauca (mostly C. gloeosporioides). Meanwhile, the third group was formed by isolates V42, V46, and V54 from Valle del Cauca, SCP from Risaralda, and S31 from Quindío. The fourth group had two subgroups: 4A and 4B. Both were composed of isolates mostly from Caldas, Risaralda, and Quindío, which indicated that these isolates showed great genetic similarity, possibly because of their geographical proximity. According to Tuskan et al. (1990), more than one gene may be responsible for this behavior, and it is possible that many genes are involved in the varying degrees of adaptation to different climatic conditions attributed to the broad variability of $C$. gloeosporioides and its ability to adapt to different regions with different climatic conditions and different physiological characteristics of the host plant.

\section{CONCLUSIONS}

Thirty microsatellite primer pairs were developed, 10 of which showed polymorphisms in the populations analyzed and 10 of which amplified samples of $C$. gloeosporioides and C. acutatum, demonstrating transferability of the microsatellite primers developed.

When genetic diversity parameters were assessed, the microsatellite pairs helped identify multiallelic markers and $H_{\mathrm{O}}$ values higher than $H_{\mathrm{E}}$ values. Differentiation was also observed between the species $C$. gloeosporioides and $C$. acutatum. The tendency of isolates to group according to geographical origin evidenced the existence of significant intraspecific genetic variability because of their short life cycle and sexual and asexual reproduction.

The molecular tools developed will serve to identify $C$. gloeosporioides isolates causing anthracnose in other crops, especially tropical fruits.

\section{ACKNOWLEDGMENTS}

Research supported by the Ministry of Agriculture and Rural Development of Colombia and the Universidad Tecnológica de Pereira. We are very grateful to Dr. Anete Pereira de Souza and her staff at the Universidade Estadual de Campinas (UNICAMP) in Campinas, São Paulo, Brazil, for their support during the development of the microsatellite-enriched genomic library.

\section{REFERENCES}

Abang M, Winter S, Mignouna H, Green K, et al. (2003). Molecular taxonomic, epidemiological and population genetic approaches to understanding yam anthracnose disease. Afr. J. Biotechnol. 2: 486-496.

Afanador L, Álvarez E and González A (2006). Anthracnose of Blackberry (Rubus glaucus Benth.): Variability in Species and Races of the Causal Agent and Identification of Sources of Resistance to the Disease. In: Crop and Agroecosystem Health Management Project PE - I. Annual Report. CIAT, Cali, 72-76.

Agrios G (1996). Fitopatología. 2nd edn. Limusa.

Alahakoon PW, Brown AE and Sreenivasaprasad S (1994). Cross-infection potential of genetic groups of Colletotrichum gloeosporioides on tropical fruits. Physiol. Mol. Plant Pathol. 44: 93-103.

Benbouza H, Jacquemin JM, Baudoin JP and Mergeai G (2006). Optimization of a reliable, fast, cheap and sensitive silver staining method to detect SSR markers in polyacrylamide gels. Biotechnol. Agron. Soc. Environ. 10: 77-81.

Billotte N, Lagoda PJR, Risterucci AM and Baurens FC (1999). Microsatellite-enriched libraries: Applied methodology for the development of SSR markers in tropical crops. Fruits 54: 277-288. 
Bogale M, Steenkamp ET, Wingfield MJ and Wingfield BD (2009). Diverse Fusarium solani isolates colonize agricultural environments in Ethiopia. Eur. J. Plant Pathol. 124: 369-378.

Brown AE, Sreenivasaprasad S and Timmer LW (1996). Molecular characterization of slow-growing orange and key lime anthracnose strains of Colletotrichum from citrus as C. acutatum. Phytopathology 86: 523-527.

Cannon PF, Damm U, Johnston PR and Weir BS (2012). Colletotrichum - current status and future directions. Stud. Mycol. 73: $181-213$

Casarrubias-Carrillo U, González-Chavira M, Cruz-Hernández A and Cárdenas-Soriano E (2003). Variabilidad genética de Colletotrichum gloeosporioides (Penz.) Penz. y Sacc. aislado de frutos de papaya (Carica papaya L.) mediante el uso de marcadores moleculares RAPD. Rev. Mex. Fitopatol. 3: 338-345.

Cedeño LR and Palacios EL (1992). Antracnosis en mora de Castilla (Rubus glaucus) causada por Glomerella cingulata en Venezuela. Fitopatol. Venez. 4: 17-20.

Ciampi MB, Meyer MC, Costa MJ, Zala M, et al. (2008). Genetic structure of populations of Rhizoctonia solani anastomosis group-1 IA from soybean in Brazil. Phytopathology 98: 932-941.

Cordeiro GM, Taylor GO and Henry RJ (2003). Characterization of microsatellite markers from sugar cane (Saccharum sp.), highly polyploidy species. Plant Sci. 155: 161-168.

Dean R, Van Kan JA, Pretorius ZA, Hammond-Kosack KE, et al. (2012). The Top 10 fungal pathogens in molecular plant pathology. Mol. Plant Pathol. 13: 414-430.

Denoyes-Rothan B, Guérin G, Délye C, Smith B, et al. (2003). Genetic diversity and pathogenic variability among isolates of Colletotrichum species from strawberry. Phytopathology 93: 219-228.

Dereeper A, Argout X, Billot C and Rami JF (2007). SAT, a flexible and optimized web application for SSR marker development. BMC Bioinf. 8: 465.

Feres JM, Martinez ML, Martinez CA, Mestriner MA, et al. (2009). Transferability and characterization of nine microsatellite markers for the tropical tree species Tabebuia roseo-alba. Mol. Ecol. Resour. 9: 434-437.

Freeman S (2000). Genetic Diversity and Host Specificity of Colletotrichum Species on Various Fruits. In: Colletotrichum Host Specificity, Pathology, and Host-Pathogen Interaction (Prusky D, Freeman S and Dickman M, eds.). APS Press, 131-144.

González M, Rodríguez R, Zavala ME, Jacobo JL, et al. (1998). Characterization of Mexican isolates of Colletotrichum lindemuthianum by using differential cultivars and molecular markers. Phytopathology 88: 292-299.

Gunnell PS and Gubler WD (1992). Taxonomy and morphology of Colletotrichum species pathogenic on strawberry. Mycologia 84: 157-165.

Lee SB and Taylor JW (1990). Isolation of DNA from Fungal Mycelia and Single Spores. Chapter 34. In: PCR Protocols: A Guide to Methods and Applications (Innis M, Gelfand D, Sninsky J and White T, eds.). Academic Press, Orlando, 282-287.

MacKenzie S, Legard D, Timmer L, Chandler C, et al. (2006). Resistance of strawberry cultivars to crown rot caused by Colletotrichum gloeosporioides isolates from Florida is nonspecific. Plant Dis. 90: 1091-1097.

MacLean DJ, Braithwaite KS, Manners JM and Irwing JAG (1993). How do we identify and classify fungal pathogens in the era of DNA analysis? Adv. Plant Pathol. 10: 207-244.

Marulanda ML, Isaza L and Ramírez AM (2007). Identificación de la especie de Colletotrichum responsable de la antracnosis en la mora de Castilla en la región cafetera. Sci. Technol. 37: 585-590.

Masel A, Braithwaite K, Irwin J and Manners J (1990). Highly variable molecular karyotypes in the plant pathogen Colletotrichum gloeosporioides. Curr. Genet. 18: 81-86.

McDonald BA and Linde C (2002). The population genetics of plant pathogens and breeding strategies for durable resistance. Euphytica 124: 163-180.

Medeiros LV, Maciel DB, Medeiros VV, Houllou Kido LM, et al. (2010). pelB gene in isolates of Colletotrichum gloeosporioides from several hosts. Genet. Mol. Res. 9: 661-673.

Michereff SJ (2000). Quantificação de Doenças de Plantas. In: Desafio do Manejo Integrado de Pragas e Doenças. Livro de Palestras e Mini-Cursos "Semana de Fitossanidade" Editora Universitária da UFPE, Recife, 63-77.

Montero TV, Montalvo HL, Morales GL and Azpiroz RS (1998). Estimación de la Variabilidad Genética Intrapoblacional Mediante el uso de Fragmentos de DNA Amplificados al azar. Memorias del XVII Congreso de Fitogenética, Acapulco, 348 .

Nei M (1978). Estimation of average heterozygosity and genetic distance from a small number of individuals. Genetics 89: $583-590$.

Peakall R and Smouse PE (2006). GENALEX 6: Genetic analysis in Excel. Population genetics software for teaching and research. Mol. Ecol. Notes 6: 288-295.

Ranathunge NP, Ford R and Taylor PW (2009). Development and optimization of sequence-tagged microsatellite site 
markers to detect genetic diversity within Colletotrichum capsici, a causal agent of chilli pepper anthracnose disease. Mol. Ecol. Resour. 9: 1175-1179.

Smith BJ and Black L (1990). Morphological, cultural, and pathogenic variation among Colletotrichum species isolated from strawberry. Plant Dis. 74: 69-76.

Tamayo PJ (2003). Principales Enfermedades del Tomate de Árbol, la Mora y el Lulo en Colombia. Boletín Técnico 20. CORPOICA-Regional 4. Rionegro, Antioquia.

Tuskan GA, Walla JA and Lundquist JE (1990). Genetic-geographic variation in Peridermium harknessii in the northcentral United States. Phytopathology 80: 857-861.

White TJ, Bruns T, Lees S and Taylor JW (1990). Amplification and Direct Sequencing of Fungal Ribosomal RNA Genes for Phylogenetics. In: PCR Protocols: A Guide to Methods and Applications (Inss MA, Gelfand DH and Sninsky JJ, eds.). Academic Press, San Diego, 315-322. 